\title{
Reported history and correlates of drug overdose among people who inject drugs in Lebanon
}

Kaveh Khoshnood, ${ }^{1}$ Fatma Shebl, $, 3,3$ Danielle Khouri, ${ }^{4}$ Elie Aaraj, ${ }^{5}$ Russell Barbour, ${ }^{1}$ Forrest Crawford, ${ }^{6,7,8,9}$ Jacques Mokhbat, ${ }^{10}$ Alyssa Parpia ${ }^{1}$ and Robert Heimer $^{1}$

${ }^{1}$ Department of Epidemiology of Microbial Diseases and Center for Interdisciplinary Research on AIDS at Yale; ${ }^{2}$ Department of Chronic Disease Epidemiology, Yale School of Public Health; ${ }^{6}$ Department of Biostatistics and the Public Health Modeling Unit, Yale School of Public Health, ${ }^{7}$ Department of Ecology \& Evolutionary Biology; ${ }^{8}$ Department of Statistics \& Data Science, ${ }^{9}$ Yale School of Management, Yale University, New Haven, United States of America (Correspondence to: Kaveh Khoshnood: Kaveh.Khoshnood@yale.edu). ${ }^{3}$ Medical Practice Evaluation Center, Massachusetts General Hospital, Harvard Medical School, Boston, United States of America. ${ }^{4}$ Consultant with Middle East and North Africa Harm Reduction Association, Sin-el-Fil, Lebanon. ${ }^{5}$ Middle East and North Africa Harm Reduction Association, Sin-el-Fil, Lebanon. ${ }^{10}$ Lebanese American University Medical Center Rizk Hospital, Lebanese American University School of Medicine, Beirut, Lebanon.

\begin{abstract}
Background: Opioid overdose is an issue of increasing concern, and better epidemiologic data are needed to implement effective treatment programmes. Few published reports address the frequency of fatal or non-fatal opioid overdose in countries in the Middle East and North Africa region.
\end{abstract}

Aims: We provide the first-ever study of the reported history and correlates of drug overdose among a broad sample of out-of-treatment people who inject drugs (PWID) in Lebanon.

Methods: This was a respondent-driven sampling, cross-sectional, biobehavioural study carried out in Beirut, Lebanon, between October 2014 and February 2015. Data were collected on sociodemographics, risk profiles, drug use histories, drug and sexual risk behaviours, history of substance use treatment and incarceration, and pertinent infectious disease test results.

Results: We recruited 382 eligible PWID. The majority were Lebanese (95.3\%) men (95.5\%), with an average age of 30.3 (standard deviation 9.9) years. A history of drug overdose was reported in 171 (44.8\%) PWID. Around 86\% reported heroin as the first drug they had ever injected. Approximately half (53.0\%) reported a history of substance use treatment, and $80.1 \%$ reported a history of arrest for the injection or possession of drugs. Our analysis demonstrates that, after adjusting for relevant covariates, drug overdose is associated with a history of incarceration, drug treatment, and an increased number of arrests in one's lifetime for drug injection or possession.

Conclusions: The observed associations suggest overdose prevention programmes may be effective if targeted to recently incarcerated people and to those receiving drug treatment.

Keywords: PWID, opioid, overdose, risk behaviours, Lebanon

Citation: Khoshnood K; Shebl F; Khoury D; Aaraj E; Barbour R, Crawford F, et al. Reported history and correlates of drug overdose among people who inject drugs in Lebanon. East Mediterr Health J. 2021;27(6):571-579. https://doi.org/10.26719/2021.27.6.571

Received: 04/12/20, accepted: 20/12/20

Copyright (c) World Health Organization (WHO) 2021. Open Access. Some rights reserved. This work is available under the CC BY-NC-SA 3.0 IGO license (https://creativecommons.org/licenses/by-nc-sa/3.o/igo).

\section{Introduction}

Drug overdose is a public health concern that affects diverse populations across the globe (1). Nevertheless, there are few published reports on the frequency of fatal or non-fatal opioid overdose in the Middle East and North Africa (MENA) region. We therefore conducted the first study of non-fatal drug overdose in Lebanon. In recent years, increasing attention has focused on overdose related to illicit opioid consumption. Overdose deaths, which are attributable in most cases to opioids, contribute to between one-third and one-half of all drug-related deaths (2). Opioids affect the part of the brain that regulates breathing, and excessive doses-overdoses-can cause respiratory depression and death. Opioid use disorder increases the risk of overdose, particularly in context of opioid use following a period of voluntary abstinence, release from incarceration, or cessation of treatment for opioid use disorder, when opioid tolerance is diminished
(3-9). Alcohol or sedative consumption concurrent with opioid use also increases the risk of overdose.

It is estimated that mortality among people who inject drugs (PWID), which are frequently opioids, is 14 times greater than that of the general population (2). A 2012 study estimated that about 69000 people die every year from opioid overdose globally (3), but this research relies on data prior to the recent rise in opioid-overdose deaths in North America, Europe, and Australia, which have reached crisis proportions (10-12). Drug overdose can be either intentional (in cases of attempted suicide) or unintentional (e.g. too much of a drug taken accidentally or the wrong drug or doses given or taken in error), with unintentional overdose being far more common (13). Non-fatal overdoses are a strong predictor of future fatal overdose $(14,15)$. The National Center for Injury Prevention and Control in the United States of America is among the many organizations that argue that "drug overdose should 
be treated as an injury to which prevention strategies should be applied" (16). Effective interventions, including the wide-scale distribution of naloxone, have proven to be effective strategies to reduce fatal overdoses among opioid users $(15,17)$. Other effective interventions include continuous opioid agonist therapy, extended release or implanted opioid antagonist, treatment of co-occurring substance use, and collaboration with law enforcement to reduce the risk environment $(10,18)$.

There is a limited understanding of the burden of drug overdose among PWID, particularly in low- and-middle income countries. The few publications that do exist, mostly from southeast Asia, reveal a significant burden of non-fatal overdose among PWID as well as a high prevalence of witnessing overdoses among drug-using peers $(19,20)$. There are limited data on opioid use disorder and its complications in the Arab countries in the MENA region, and prior estimates may be unreliable. According to the World Health Organization, the prevalence of drug use disorder and injection drug use in the Eastern Mediterranean Region is estimated to be 3500 per 100000 and 172 per 100000 , respectively, accounting for a loss of 4 disability-adjusted life years (DALYs) and 9 deaths per 1000 population (21). There are even fewer data on the frequency of fatal or non-fatal opioid overdose from Arab countries in the Region $(22,23)$. Here, we provide the first-ever study of the prevalence and correlates of nonfatal opioid overdose among a broad sample of out-oftreatment PWID in Lebanon.

\section{Methods}

\section{Survey}

This analysis relies on data from a larger study conducted in 2014-15 by a team of Lebanese and American researchers and a local field team with staff from 4 established nongovernmental organizations working on substance use and HIV/AIDS prevention issues. The primary aims of the larger study were to estimate the population size of PWID and men who have sex with men in the greater Beirut area, and to estimate the prevalence of bloodborne infections (HIV and HCV) and associated risk factors in these 2 populations. In addition to the data needed for PWID population size and infection prevalence estimation, we collected quantitative demographic and sexual and drug use behavioural data using a structured questionnaire (see below) that included 3 questions on drug overdose: "Have you ever experienced a drug overdose when you lost consciousness or stopped breathing?" "How many overdoses have you experienced?" and "How many times have you experienced a drug overdose in the last 12 months?"

The absence of sampling frames for the random recruitment of individuals within PWID populations led us to employ respondent-driven sampling to accrue study participants (24). Respondent-driven sampling relies on a chain referral approach in which each enrolled participant was given 4 coupons to recruit others eligible to participate from within their social network of individuals in the hidden population. The field staff, seasoned outreach workers with long histories of working with PWID, identified and recruited the first set of PWID participants, known as "seeds." Subsequently, individuals who presented coupons to join the study were screened for eligibility using 2 qualifying criteria: the presence of injection stigmata or, if none, the selfreporting of injection in the past 3 months followed by a convincing description of the drug injection process. In our study, recruitment ended on a specific date, 4 months after the first seeds were enrolled.

In brief, our structured questionnaire followed the framework of the Integrated Bio-Behavioral Survey toolbox, a free publicly available tool available from the University of San Francisco Institute for Global Health Sciences and developed in conjunction with the HIV epidemiology section of the San Francisco Department of Public Health (25). The authors of this tool indicate that this survey was designed to produce "high-quality, user-friendly, practical, reliable and reproducible data to inform policy and programmes to improve the health of HIV-affected populations and reduce the spread of the virus" (25). This survey tool has been used in published research in at least 8 countries in Eastern Europe, Africa and Asia (26).

We added questions to collect additional details of injection drug-using behaviours. The survey was divided into major sections: sociodemographic, sexual history and current behaviours; sexual networks; drug use; social network; stigma, discrimination and violence; history of HIV and sexually transmitted infections; and for those who reported being HIV positive, HIV care experiences. The questionnaire was translated into Arabic and then back into English and finalized through pilot testing with field staff from the local agencies.

Further details on study protocol, recruitment methodology (using respondent-driven sampling), data collection instruments, and the HIV and HCV testing approach are detailed elsewhere (26). Ethical approval was obtained from the Institutional Review Board at the Lebanese American University.

\section{Statistical methods}

Our research team analysed survey data using $R$, version 3.5.1, to determine the characteristics of the sample, describe the frequencies of individual risk behaviours and practices, and conduct analyses. History of drug overdose was determined by self-report. We conducted descriptive bivariate analysis using Chi-square statistic by comparing the characteristics of those with and those without histories of drug overdose. We also conducted logistic regression of the correlates of drug overdose within this sample. Missing data required for the regression analysis were imputed using a random forest algorithm via the $R$ package missRanger (27).

To ensure that variance on estimates was adjusted for imputation, 100 datasets with imputed values were generated and the results were pooled using Rubin's rule. Averages of parameter estimates were obtained 
and variance was acquired by taking the average of the squared standard errors with the variance of parameter estimates across all of the imputed datasets. This resulted in inflated $P$-values and confidence intervals.

\section{Results}

\section{Participants}

We recruited a total of 390 participants, beginning with 16 PWID seeds, of whom 382 had recently engaged in injection drug use. The majority of the 382 PWID were men (95.5\%), and the mean age was 30.3 (standard deviation 9.9) years. Almost all participants were from Lebanon (95.3\%). Approximately 89\% resided in greater Beirut.
Only $15.2 \%$ had completed university or some university/ college education, $75.3 \%$ were never married or in a committed relationship, and $63.1 \%$ had no income/were not employed. Among the 382 study participants, 171 (44.8\%) reported a history of drug overdose (Table 1 ).

\section{Drug use}

Heroin was reported by $85.8 \%$ of the participants as the drug they injected the first time they used drugs (Table 2). Most individuals (92.6\%) reported injecting drugs in the past month. A history of arrest or incarceration for the injection or possession of drugs was reported by $80.1 \%$ of participants. Of those who had been incarcerated, $15.3 \%$ injected drugs while in prison. Approximately half the participants $(53.0 \%)$ reported prior engagement in sub-

\section{Table 1 Sociodemographic characteristics by overdose status among people who use drugs in Lebanon, 2014-2015}

\begin{tabular}{|c|c|c|c|}
\hline \multirow[t]{4}{*}{ Factor } & \multirow[t]{2}{*}{ Total } & \multicolumn{2}{|c|}{ Experience of overdose } \\
\hline & & Yes & No \\
\hline & $n=382$ & $n=171$ & $n=211$ \\
\hline & No. (\%) & No. (\%) & No. (\%) \\
\hline \multicolumn{4}{|l|}{ Sex } \\
\hline Male & $365(95.5)$ & $163(44.7)$ & $202(55 \cdot 3)$ \\
\hline Female & $17(4.5)$ & $8(47.1)$ & $9(52.9)$ \\
\hline \multicolumn{4}{|l|}{ Country of origin } \\
\hline Lebanon & $364(95.3)$ & $159(43.7)$ & $205(56.3)$ \\
\hline Syria & $9(2.4)$ & $5(55.6)$ & $4(44.4)$ \\
\hline Other & $8(2.1)$ & $7(87.5)$ & $1(12.5)$ \\
\hline Missing & $1(0.3)$ & $0(0.0)$ & $1(100.0)$ \\
\hline \multicolumn{4}{|l|}{ Education level } \\
\hline None & $87(22.8)$ & $36(41.4)$ & $51(58.6)$ \\
\hline Primary school & $159(41.7)$ & $64(40.3)$ & $95(59.7)$ \\
\hline Secondary school & $77(20.2)$ & $40(51.9)$ & $37(48.1)$ \\
\hline At least some university/college & $58(15.2)$ & $30(51.7)$ & $28(48.3)$ \\
\hline Missing & $1(0.3)$ & $0(0.0)$ & $1(100.0)$ \\
\hline \multicolumn{4}{|l|}{ Employment status } \\
\hline Employed & $139(36.9)$ & $61(43.9)$ & $78(56.1)$ \\
\hline Unemployed & $238(63.1)$ & $106(44.5)$ & $132(55.5)$ \\
\hline Missing & $5(1.3)$ & $4(80.0)$ & $1(20.0)$ \\
\hline \multicolumn{4}{|l|}{ Marital status } \\
\hline Married & $49(12.9)$ & $23(46.9)$ & $26(53.1)$ \\
\hline Separated/divorced & $45(11.8)$ & $20(44.4)$ & $25(55.6)$ \\
\hline Never married & $287(75.3)$ & $128(44.6)$ & $159(55.4)$ \\
\hline Missing & $1(0.3)$ & $0(0.0)$ & $1(100.0)$ \\
\hline \multicolumn{4}{|l|}{ City of residence } \\
\hline Beirut & $323(88.7)$ & $140(43.3)$ & $183(56.7)$ \\
\hline Other city & $40(11.0)$ & $22(55)$ & $18(45)$ \\
\hline Don't know/decline to answer & $1(0.3)$ & $0(0.0)$ & $1(100.0)$ \\
\hline \multirow[t]{2}{*}{ Missing } & $18(4.7)$ & $9(50.0)$ & $9(50.0)$ \\
\hline & Mean (SD) & Mean (SD) & Mean (SD) \\
\hline Age (years) & $30.3(9.9)$ & $31.1(9.4)$ & $29.6(10.4)$ \\
\hline Duration in city of residence (years) & $19.2(13.6)$ & $19.0(12.8)$ & $19.3(14.2)$ \\
\hline
\end{tabular}




\begin{tabular}{|c|c|c|c|c|}
\hline \multirow[t]{3}{*}{ Factor } & \multirow{3}{*}{$\begin{array}{c}\text { Total } \\
\text { No. (\%) }\end{array}$} & \multicolumn{2}{|c|}{ Experience of overdose } & \multirow[t]{3}{*}{ P-value } \\
\hline & & Yes & No & \\
\hline & & No. (\%) & No. (\%) & \\
\hline First drug ever injected & & & & 0.424 \\
\hline Heroin & $327(85.8)$ & $148(45 \cdot 3)$ & $179(54.7)$ & \\
\hline Cocaine & $46(12.1)$ & $17(37)$ & $29(63.0)$ & \\
\hline Methamphetamine or similar stimulant & $1(0.3)$ & $1(100.0)$ & $0(0.0)$ & \\
\hline Pharmaceutical opioid & $1(0.3)$ & $1(100.0)$ & $0(0.0)$ & \\
\hline Other (specify) & $6(1.6)$ & $3(50.0)$ & $3(50.0)$ & \\
\hline Missing & $1(0.3)$ & $1(100.0)$ & $0(0.0)$ & \\
\hline Ever arrested for drug injection or possession & & & & $<0.0001$ \\
\hline Yes & $286(80.1)$ & $149(52.1)$ & $137(47.9)$ & \\
\hline No & $71(19.9)$ & $15(21.1)$ & $56(78.9)$ & \\
\hline Missing & $25(6.5)$ & $7(28.0)$ & $18(72.0)$ & \\
\hline Ever incarcerated for drug injection or possession & & & & $<0.0001$ \\
\hline Yes & $288(76.2)$ & $153(53.1)$ & $135(46.9)$ & \\
\hline No & $90(23.8)$ & $17(18.9)$ & $73(81.1)$ & \\
\hline Missing & $4(1.0)$ & $1(25.0)$ & $3(75.0)$ & \\
\hline Ever entered substance dependence treatment for drug use & & & & $<0.0001$ \\
\hline Yes & $201(53.0)$ & $120(59.7)$ & $81(40.3)$ & \\
\hline No & $178(47.0)$ & $50(28.1)$ & $128(71.9)$ & \\
\hline Missing & $3(0.8)$ & $1(33.3)$ & $2(66.7)$ & \\
\hline Injection frequency & & & & 0.037 \\
\hline Every day & $252(66.8)$ & $127(50.4)$ & $125(49.6)$ & \\
\hline About every other day & $69(18.3)$ & $24(34.8)$ & $45(65.2)$ & \\
\hline $1-3$ times per week & $41(10.9)$ & $13(31.7)$ & $28(68.3)$ & \\
\hline Less than once per week & $15(4.0)$ & $6(40.0)$ & $9(60.0)$ & \\
\hline Missing & $5(1.3)$ & $1(20.0)$ & $4(80.0)$ & \\
\hline Drugs used & & & & 0.001 \\
\hline Heroin & $249(65.9)$ & $108(43.4)$ & $141(56.6)$ & \\
\hline Cocaine & $64(16.9)$ & $21(32.8)$ & $43(67.2)$ & \\
\hline Club drug (specify) & $3(0.8)$ & $2(66.7)$ & $1(33.3)$ & \\
\hline Pharmaceutical opioid & $33(8.7)$ & $14(42.4)$ & $19(57.6)$ & \\
\hline Other (specify) & $29(7.7)$ & $23(79.3)$ & $6(20.7)$ & \\
\hline Missing & $4(1.0)$ & $3(75.0)$ & $1(25.0)$ & \\
\hline Injected alone or shared your drugs with another person & & & & 0.068 \\
\hline Alone & $263(69.2)$ & $128(48.7)$ & $135(51.3)$ & \\
\hline With one person & $78(20.5)$ & $31(39.7)$ & $47(60.3)$ & \\
\hline With more than one person & $39(10.3)$ & $12(30.8)$ & $27(69.2)$ & \\
\hline Missing & $2(0.5)$ & $0(0.0)$ & $2(100.0)$ & \\
\hline Drug sharing & & & & 0.132 \\
\hline Drugs divided prior to dissolving & $55(42.3)$ & $20(36.4)$ & $35(63.6)$ & \\
\hline Drugs divided after dissolving & $75(57.7)$ & $29(38.7)$ & $46(61.3)$ & \\
\hline Missing & $252(66.0)$ & $122(48.4)$ & $130(51.6)$ & \\
\hline Syringe use practices & & & & 0.176 \\
\hline Syringe with a fixed needle & $337(88.7)$ & $145(43)$ & $192(57.0)$ & \\
\hline Syringe with a detachable needle & $42(11.1)$ & $25(59.5)$ & $17(40.5)$ & \\
\hline Other & $1(0.3)$ & $0(0.0)$ & $1(100.0)$ & \\
\hline Missing & $2(0.5)$ & $1(50.0)$ & $1(50.0)$ & \\
\hline
\end{tabular}




\begin{tabular}{|c|c|c|c|c|}
\hline \multicolumn{4}{|l|}{$\begin{array}{l}\text { Table } 2 \text { Drug use-related history and bel } \\
\text { (concluded) } \\
\text { Use of new syringe in most recent injection }\end{array}$} & \multirow[t]{5}{*}{0.007} \\
\hline New syringe & $259(69.1)$ & $101(39)$ & $158(61)$ & \\
\hline Not a new syringe & $115(30.7)$ & $66(57.4)$ & $49(42.6)$ & \\
\hline Don't know/decline to answer & $1(0.3)$ & $1(100.0)$ & $0(0.0)$ & \\
\hline \multirow[t]{2}{*}{ Missing } & $7(1.8)$ & $3(42.9)$ & $4(57.1)$ & \\
\hline & Mean (SD) & Mean (SD) & Mean (SD) & \\
\hline Age at first injection (years) & $19.5(5.5)$ & $18.6(4.9)$ & $20.3(58.8)$ & 0.003 \\
\hline No. of people who shared the most recent same injection site & $1.8(9.5)$ & $2.5(12.4)$ & $1.2(6.4)$ & 0.184 \\
\hline No. of people who inject drugs seen in the past four weeks & $18.8(20.3)$ & $21.7(23.4)$ & $16.5(17.2)$ & 0.014 \\
\hline No. of arrests for drug injection or possession & $4.2(5.1)$ & $5.6(5.1)$ & $3.1(4.7)$ & $<0.001$ \\
\hline
\end{tabular}

stance dependence treatment. Heroin and cocaine were the 2 most common drugs injected in the past month, reported by $65.9 \%$ and $16.9 \%$ of the participants. About $69 \%$ reported injecting alone, while 30\% reported injecting with one or more persons. Of those who reported sharing their drugs, $57.7 \%$ reported sharing the drugs after they were dissolved. About $89 \%$ reported using a syringe with a fixed needle for injection. In addition, those individuals who experienced overdose tended to be in contact with a greater number of PWID in the past month compared to individuals with no history of overdose (21.6 and 16.9 PWID respectively) (Table 2).

\section{History of overdose}

Those who reported having ever experienced a drug overdose were also significantly more likely to have ever been arrested for injecting or possessing drugs, ever been incarcerated for injecting or possessing drugs, ever participated in substance dependence treatment, inject less frequently than every day, and inject alone. They were also significantly less likely to use a syringe previously used by another person than those who reported never experiencing a drug overdose (Table 2). Those who reported an experience of drug overdose were an average of 1.5 years younger than those who had not experienced an overdose when they first injected drugs. Among those who reported to have ever overdosed, 54.0\% reported an overdose in the past year, and they reported 3.4 overdoses on average during their lifetimes.

We used a multivariable logistic regression to model the factors correlated with history of drug overdose among our study participants (Table 3). Those with a history of incarceration and engagement in substance dependence treatment and those with a greater number of arrests due to drug possession or injection in their lifetimes were more likely to report histories of drug overdose.

\section{Number of overdoses}

Of those who had experienced overdoses, individuals reporting more than one overdose event $(64.3 \%)$, compared with those reporting only a single event $(35.7 \%)$, reported a statistically significantly higher number of arrests for injecting or possessing drugs $(P=0.005)$.

\section{Recentness of overdose experiences}

We asked respondents how many times they had experienced a drug overdose in the year prior to the interview. We found that 60 individuals reported experiencing one overdose in the last year and 108 respondents experienced 2 or more drug overdoses in the last year (data not shown).

\section{Discussion}

In this first study of drug overdose, drawn from the largest sample of PWID in Lebanon to date, drug overdose was reported by almost half the study population. Those who reported a history of drug overdose were slightly younger when they first injected, were more likely to have been born outside of Lebanon (mostly in Syria), were more likely to have a history of arrest, incarceration, and substance dependence treatment, were less likely to have injected less than once per week, reported less use of cocaine and more injection of "club drugs," and were more likely to have injected with more than one person. In multivariable logistic regression analysis, 3 factors, history of incarceration, prior receipt of treatment for substance dependence, and a higher number of arrests for drug injection or possession were associated with reporting ever having experienced a drug overdose.

The proportion of our sample who reported a history of drug overdose is significantly higher than the baseline overdose prevalence reported by a study of patients in a Lebanese drug treatment programme conducted about a year before our study (22). This difference might exist because our sample was not recruited from substance use treatment programmes and may represent PWID at higher risk o)f drug overdose. Moreover, in our sample, a history of drug overdose was higher among nonLebanese (mostly Syrians), who have less access to drug treatment in Lebanon. The disparity is alarming given the large population of displaced Syrians in Lebanon and their general difficulty in accessing health care services (28). Also, the proportion of non-fatal overdose 


\begin{tabular}{|c|c|c|}
\hline Predictor & OR $(95 \%$ CI $)$ & P-value \\
\hline Age & $1.008(0.976-1.041)$ & 0.6352 \\
\hline Sex & & \\
\hline Male & 1 & \\
\hline Female & $1.438(0.431-4.803)$ & 0.5552 \\
\hline Employment status & & \\
\hline Employed & 1 & \\
\hline Unemployed & $0.969(0.593-1.585)$ & 0.9296 \\
\hline Marital status & & \\
\hline Currently married & 1 & \\
\hline Previously married & $0.657(0.261-1.658)$ & 0.3748 \\
\hline Never married & $0.955(0.458-1.995)$ & 0.9032 \\
\hline Education level & & \\
\hline $\begin{array}{l}\text { Some/completed university or } \\
\text { college }\end{array}$ & 1 & \\
\hline No primary school & $0.958(0.415-2.212)$ & 0.9194 \\
\hline Completed primary school & $0.881(0.416-1.865)$ & 0.7402 \\
\hline Completed secondary school & $0.861(0.388-1.909)$ & 0.7130 \\
\hline Injection frequency & & \\
\hline Less than once a week & 1 & \\
\hline Everyday & $2.21(0.68-7.187)$ & 0.1884 \\
\hline About every other day & $1.915(0.528-6.945)$ & 0.3238 \\
\hline One to three times a week & $1.14(0.299-4.349)$ & 0.8479 \\
\hline $\begin{array}{l}\text { Incarcerated for drug injection } \\
\text { or possession }\end{array}$ & & \\
\hline Never incarcerated & 1 & \\
\hline Incarcerated & $13.073(1.972-86.654)$ & 0.0081 \\
\hline $\begin{array}{l}\text { Prior engagement in substance } \\
\text { dependence treatment }\end{array}$ & & \\
\hline Never in treatment & 1 & \\
\hline Treatment & $3.064(1.854-5.064)$ & $<0.0001$ \\
\hline $\begin{array}{l}\text { Arrested for drug injection or } \\
\text { possession }\end{array}$ & & \\
\hline Never arrested & 1 & \\
\hline Arrested & $0.179(0.028-1.13)$ & 0.0681 \\
\hline $\begin{array}{l}\text { No. of arrests for drug injection } \\
\text { or possession }\end{array}$ & $1.068(1.01-1.129)$ & 0.0209 \\
\hline $\begin{array}{l}\text { No. of people who inject drugs } \\
\text { you have seen in the past } 4 \\
\text { weeks }\end{array}$ & $1.012(0.999-1.026)$ & 0.0805 \\
\hline Age of first drug injection & $0.955(0.903-1.009)$ & 0.1027 \\
\hline
\end{tabular}

Missing values were imputed using a random forest imputation. P-values and confidence intervals (CI) have been adjusted for imputation. $\mathrm{OR}=$ odds ratio.

in our study is consistent with the proportion reported by a systematic review published in 2019, which reported that $20.5 \%$ and $41.5 \%$ of PWID had experienced non-fatal overdose in the previous 12 months and in their lifetimes, respectively (29).

A majority of those who reported a history of drug overdose in our study had prior experience with substance use treatment programmes, and three-quarters had been incarcerated. Our findings are consistent with other studies that found similar associations (4-9). These institutional interactions could provide important opportunities for intervention, offering individuals overdose prevention education and training programmes and access to naloxone. This intervention is particularly important for those leaving prisons, as the likelihood of drug overdose is significantly higher after release (30-33).

Lebanon can consider modelling its overdose prevention programmes after those which already exist at drug treatment centres or in prison systems in other countries (34). We presented our study findings to a group of stakeholders, including treatment and criminal justice representatives, and we plan to use our contacts with these institutions as a springboard to further disseminate our research and to discuss developing and implementing overdose prevention efforts in their systems. We are also in the process of obtaining information about the availability of naloxone and its provision in emergency department ambulances. The strong social ties that exist between those experiencing overdose episodes suggest that overdose programmes that use word-of-mouth to offer overdose prevention and response training could reach the more vulnerable, especially if naloxone was available for community-based distribution.

Our study has several limitations. We relied on selfreporting to capture history of drug overdose, which may reflect inaccurately its prevalence. Also, our findings are not necessarily applicable to larger geographic areas or to other groups of PWID. The final limitation of our study is the 5-year lag time from the recruitment of study participants to the publication of the results. However, we are not aware of any publications on this research topic and with this study population during this time period.

\section{Conclusion}

In our sample of out-of-treatment PWID in the greater Beirut area, almost half reported a history of drug overdose and most had experienced incarceration and substance use treatment. This observed association suggests that overdose prevention programmes may be effective if targeted to recently incarcerated people and to those receiving drug treatment. Community-based interventions also have the potential to reach those at risk. 


\section{Acknowledgement}

The authors thank the field staff drawn from among the outreach workers at partner nongovernmental organizations.

Funding: This work was conducted using funds provided by the Middle East and North Africa Harm Reduction Association.

Competing interests: None declared.

\section{Antécédents et corrélats rapportés de l'overdose d'opioïdes chez les consommateurs de drogues injectables au Liban}

\section{Résumé}

Contexte: Le problème de l'overdose d'opioïdes est une préoccupation croissante, et de meilleures données épidémiologiques sont nécessaires pour mettre en œuvre des programmes de traitement efficaces. Peu de rapports publiés traitent de la fréquence des overdoses d'opioïdes mortelles ou non dans les pays de la Région du MoyenOrient et de l'Afrique du Nord.

Objectifs : Nous présentons la toute première étude sur les antécédents et les corrélats rapportés d'overdoses de drogues dans un large échantillon de consommateurs de drogues injectables hors traitement au Liban.

Méthodes : Il s'agissait d'une étude biocomportementale transversale, par échantillonnage dirigé par les répondants, réalisée à Beyrouth (Liban) entre octobre 2014 et février 2015. Des données ont été recueillies sur les caractéristiques sociodémographiques, les profils de risque, les antécédents de consommation de drogues, les comportements à risque en matière de drogues et de sexualité, les antécédents de traitement et d'incarcération liés à l'utilisation de substances psychoactives et les résultats de tests pertinents sur les maladies infectieuses.

Résultats: Nous avons recruté 382 consommateurs de drogues injectables éligibles. La majorité étaient des hommes (95,5\%) libanais (95,3\%), avec un âge moyen de 30,3 ans (écart type 9,9). Un antécédent d'overdoses a été rapporté pour 171 consommateurs de drogues injectables (44,8\%). Environ $86 \%$ ont déclaré que l'héroïne était la première drogue qu'ils avaient jamais injectée. Près de la moitié (53,0 \%) ont signalé des antécédents de traitement lié à l'utilisation de substances psychoactives, et 80,1 \% ont rapporté des antécédents d'arrestation pour injection ou possession de drogues. Notre analyse démontre quaprès ajustement pour tenir compte des covariables pertinentes, l'overdose de drogue est associée à des antécédents d'incarcération, de traitement médicamenteux et à un nombre accru d'arrestations au cours de la vie pour injection ou possession de drogue.

Conclusions: Les associations observées suggèrent que les programmes de prévention des overdoses pourraient être efficaces s'ils ciblaient les personnes récemment incarcérées et celles recevant un traitement médicamenteux.

$$
\begin{aligned}
& \text { السو ابق المبلغ بها و العو امل المرتبطة بتعاطي جرعة مفرطة من المخدرات بين الأشخاص الذين يتعاطون المخدرات } \\
& \text { حقنًا في لبنان } \\
& \text { كافي خُشنود، فاطمة شبل، دانيال خوري، إيلي عراج، راسل باربور، فورست كراوفورد، جاك خباط، آليسا باربيا، روبرت هايمر }
\end{aligned}
$$

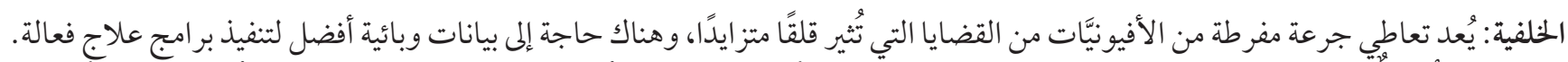

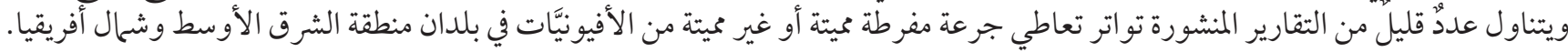

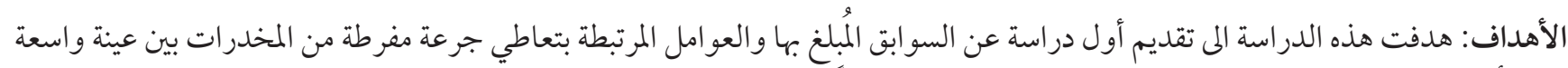

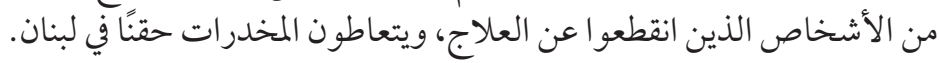

طرق البحث: تمثلت الدراسة في أخذ العينات من المستجيبين، وإجر اء دراسة مقطعية بيولوجية سلو كية في بيروت، لبنان، بين أكتوبر / تشرين الأول

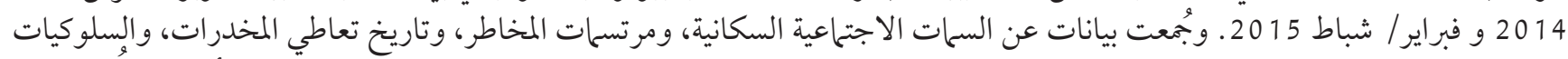

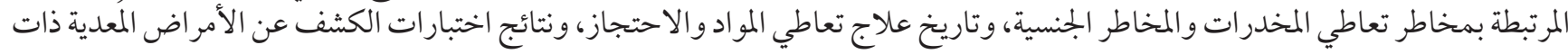

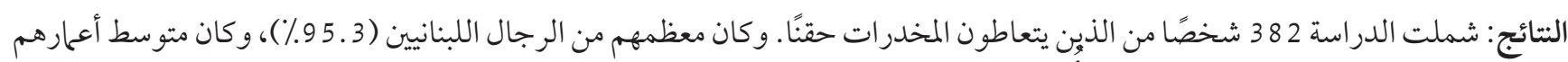

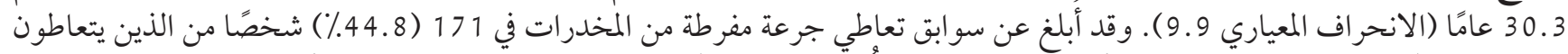

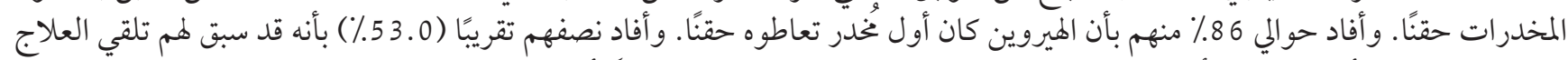

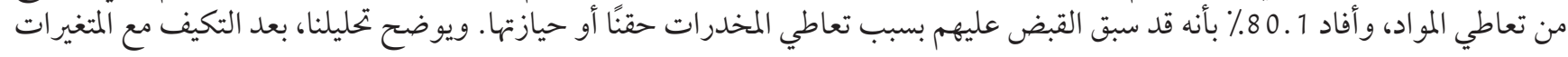




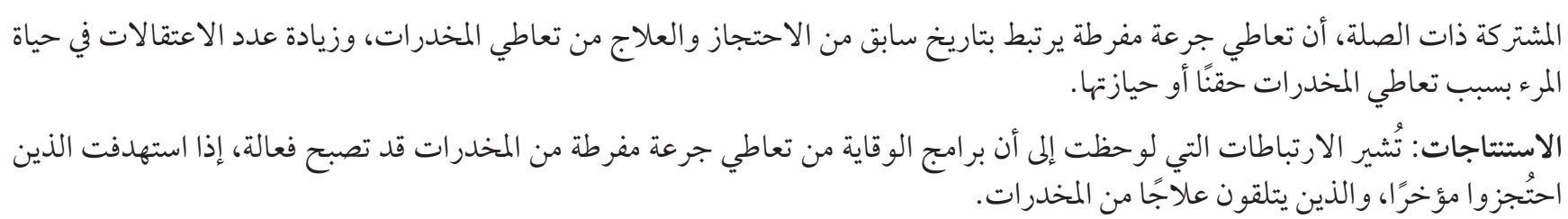

\section{References}

1. Martins S, Sampson L, Cerdá M, Galea S. Worldwide prevalence and trends in unintentional drug overdose: a systematic review of the literature. Am J Public Health. 2015;105:e29-e49. doi:10.2105/AJPH.2015.302843.

2. Information sheet on opioid overdose. August 2018. Geneva: World Health Organization; (https://www.who.int/news-room/factsheets/detail/opioid-overdose, accessed 4 February 2021).

3. Degenhardt L, Hall W. Extent of illicit drug use and dependence, and their contribution to the global burden of disease. Lancet. $2012 \operatorname{Jan}$ 7;379(9810):55-70. doi:10.1016/S0140-6736(11)61138-0

4. Bird SM, Hutchinson SJ. Male drugs-related deaths in the fortnight after release from prison: Scotland, 1996-99. Addiction. 2003;98:185-90. doi:10.1046/j.1360-0443.2003.00264.x

5. Farrell M, Marsden J. Acute risk of drug-related death among newly released prisoners in England and Wales. Addiction. 2008;103:251-5. doi:10.1111/j.1360-0443.2007.02081.x. PMID: 18199304

6. Bukten A, Stavseth MR, Skurtveit S, Tverdal A, Strang J, Clausen T. High risk of overdose death following release from prison: variations in mortality during a 15-year observation period. Addiction. 2017;112:1432-9. doi:10.1111/add.13803

7. Strang J, Beswick T, Gossop M. Loss of tolerance and overdose mortality after inpatient opiate detoxification: follow up study. BMJ. 2003;326:959-6o. doi:10.1136/bmj.326.7396.959

8. Davoli M, Bargagli AM, Perucci CA, Schifano P, Belleudi V, Hickman M et al. Risk of fatal overdose during and after specialist drug treatment: the VEdeTTE study, a national multi-site prospective cohort study. Addiction. 2007;102:1954-9. doi:10.1111/j.13600443.2007.02025.X

9. Sordo L, Barrio G, Bravo MJ, Indave BI, Degenhardt L, Wiessing L, et al. Mortality risk during and after opioid substitution treatment: systematic review and meta-analysis of cohort studies. BMJ. 2017;357:j1550. doi:10.1136/bmj.j1550. PMID: 28446428

10. Wheeler E, Davidson PJ, Jones TS, Irwin KS. Community-based opioid overdose prevention programmes providing naloxoneUnited States, 2010. Morb. Mortal. Wkly. 2012;61:101-5. PMID:22337174

11. Roxburgh A, Bruno R, Larance B, Burns L. Prescription of opioid analgesics and related harms in Australia. Med. J Aust. 2011;195(5):280-4. doi:10.5694/mja10.11450

12. Casati A, Sedefov R, Pfeiffer-Gerschel T. Misuse of medicines in the European Union: a systematic review of the literature. Eur. Addict. Res. 2012;18(5):228-45. doi:10.1159/000337028

13. Darke S, Mattick R, Degenhardt L. The ratio of non-fatal to fatal overdose. Addiction. 2003;98:1169-70. doi:10.1046/j.13600443.2003.00474.x

14. Caudarella A, Dong H, Milloy MJ, Kerr T, Wood E, Hayashi K. Non-fatal overdose as a risk factor for subsequent fatal overdose among people who inject drugs. Drug Alcohol Depend. 2016 May 1;162:51-5. doi:10.1016/j.drugalcdep.2016.02.024

15. Opioid overdose: preventing and reducing opioid overdose mortality. Discussion paper Vienna: United Nations Office on Drugs and Crime, World Health Organization; 2013 (https://www.unodc.org/docs/treatment/overdose.pdf, accessed 4 February 2021).

16. Paulozzi LJ. Overdoses are injuries too. Inj. Prev. 2007;13:293-4. doi:10.1136/ip.2007.016113.

17. Kim D, Irwin K, Khoshnood K. Expanded access to naloxone: options for critical response to the epidemic of opioid overdose mortality. Am J Public Health. 2009 March;99(3):402-7. doi:10.2105/AJPH.2008.136937

18. Community management of opioid overdose. Geneva: World Health Organization; 2014 (https://www.who.int/publications/i/ item/9789241548816, accessed 4 February 2021).

19. Bazazi AR, Zelenev A, Fu JJ, Yee I, Kamarulzaman A, Altice FL. High prevalence of non-fatal overdose among people who inject drugs in Malaysia: correlates of overdose and implications for overdose prevention from a cross-sectional study. Int J Drug Policy. 2015 July;26(7):675-81. doi:10.1016/j.drugpo.2014.11.010

20. Blackburn NA, Lancaster KE, Ha TV, Latkin CA, Miller WC, Frangakis C et al. Characteristics of persons who inject drugs and who witness opioid overdoses in Vietnam: a cross-sectional analysis to inform future overdose prevention programs. Harm Reduct J. 2017;14:62. doi:10.1186/s12954-017-0188-4.

21. Atlas: substance use in the Eastern Mediterranean Region 2015. Cairo: World Health Organization, Regional Office for the Eastern Mediterranean. 2017 (https://apps.who.int/iris/handle/10665/254675, accessed 4 February 2021).

22. Ghaddar A, Abbas Z, Haddad R. Opiate agonist treatment to improve health of individuals with opioid use disorder in Lebanon. Harm Reduct J. 2017;14:78. doi:10.1186/s12954-017-0204-8

23. Hadidi MS, Ibrahim MI, Abdallat IM, Hadidi KA. Current trends in drug abuse associated fatalities-Jordan, 2000-2004. Forensic Sci Int. 2009;18:44-7. doi:10.1016/j.forsciint.2009.01.012 
24. Heckathorn DD. Respondent-driven sampling; a new approach to the study of hidden populations. Soc Probl. 1997;44:174-99. doi:10.2307/3096941

25. Global Strategic Information. Toolbox for conducting integrated HIV bio-behavioral surveillance (IBBS) in key populations. San Francisco: University of California, Global Strategic Information; 2014 (https://globalhealthsciences.ucsf.edu/sites/globalhealthsciences.ucsf.edu/files/ibbs-intro.pdf, accessed 4 February 2021).

26. Heimer R, Barbour R, Khoury D, Crawford FW, Shebl F, Aaraj E, Khoshnood K. HIV risk, prevalence, and access to care among men who have sex with men in Lebanon. AIDS Res Hum Retroviruses. 2017 November;33(11):1149-54. doi:10.1089/AID.2016.0326.

27. Stekhoven DJ. Nonparametric missing value imputation using random forest. 2016 (https://cran.rproject.org/web/packages/ missForest/missForest.pdf, accessed 24 September 2020).

28. Health access and utilization survey among Syrian refugees in Lebanon. Geneva: United Nations High Commission on Refugees; 2019 (https://data2.unhcr.org/en/documents/details/67944, accessed 4 February 2021).

29. Colledge S, Peacock A, Leung J, Larney S, Grebely J, Hickman M, et al. The prevalence of non-fatal overdose among people who inject drugs: a multi-stage systematic review and meta-analysis. Int J Drug Policy. 2019;73:172-84. doi:10.1016/j.drugpo.2019.07.030.

30. Binswanger IA, Stern MF, Deyo RA, Heagerty PJ, Cheadle A, Elmore JG et al. Release from prison-a high risk of death for former inmates. N Engl J Med. 2007 January 11;356(2):157-65. doi:10.1056/NEJMsa064115.

31. Seaman SR, Brettle RP, Gore SM. Mortality from overdose among injecting drug users recently released from prison: database linkage study. BMJ. 1998;316:426-8. doi:10.1136/bmj.316.7129.426

32. Bird SM, Hutchinson SJ. Male drugs-related deaths in the fortnight after release from prison: Scotland, 1996-99. Addiction. 2003;98:185-90. doi:10.1046/j.1360-0443.2003.00264.X

33. Farrell M, Marsden J. Acute risk of drug-related death among newly released prisoners in England and Wales. Addiction. 2008;103:251-5. doi:10.1111/j.1360-0443.2007.02081.x

34. Parmar MK, Strang J, Choo L, Meade AM, Bird SM. Randomized controlled pilot trial of naloxone-on-release to prevent post-prison opioid overdose deaths. Addiction. 2017 March;112(3):502-15. doi:10.1111/add.13668. 